\title{
Investigation of persistent coherent structures along the Southern Brazilian Shelf
}

\author{
Maximilian Joachim Hodapp ${ }^{*}$, Eduardo de Paula Kirinus ${ }^{2}$, Wiliam Correa Marques ${ }^{3}$, Phelype \\ Haron Oleinik', Osmar Olinto Moller ${ }^{2}$
}

\author{
${ }^{1}$ Instituto de Recursos Naturais. Universidade Federal de Itajubá \\ (Av. BPS, 1303, Bairro Pinheirinho, Itajubá - MG, 37500903 - Brazil) \\ ${ }^{2}$ Instituto de Oceanografia da Universidade Federal de Rio Grande \\ (km 8, Av. Itália - Carreiros, Rio Grande - RS - 96.201-900- Brazil) \\ ${ }^{3}$ Instituto de Matemática da Universidade Federal do Rio Grande \\ (km 8, Av. Itália - Carreiros, Rio Grande - RS - 96.201-900- Brazil) \\ ${ }^{4}$ Escola de Engenharia da Universidade Federal do Rio Grande \\ (km 8, Av. Itália - Carreiros, Rio Grande - RS - 96.201-900- Brazil) \\ *Corresponding author: mhodapp@unifei.edu.br
}

\section{ABSTRACT}

The freshwater-influenced region of the Patos Lagoon discharge to the Southern Brazilian Shelf (SBS) is a region of complex fluid dynamics. Seasoning and synoptic variable winds and coastal current conditions create an alternating flow pattern. The aim of this paper was to investigate the occurrence of persistent coherent structures in this environment. A numerical approach was chosen to describe the main hydrodynamic features of the region during a climatological year. The open-source finite-element code TelemacMascaret was applied to the three-dimensional domain. In addition the two-equation k-epsilon model described the turbulence mechanisms. The presence of persistent high-turbulent structures was identified within the study area. These occur as a strong curvilinear disturbance characterized by higher turbulent production and dissipation rates, which increase local mixture. As a result, upward circulation flow was observed, which may be due to irregularities in bottom topography associated with wind-induced stress forces. These results increase the information about the circulation structures of the study area by means of numerical modelling analysis.

Descriptors: Coastal current, Coherent structures, Turbulence, TELEMAC3D, Finite element method.

Submitted on: 28/July/2017

Approved on: 11/March/2018

http://dx.doi.org/10.1590/S1679-87592018005906602

\section{Resumo}

Dentre as diferentes influências que a hidrodinâmica da plataforma continental sul brasileira sofre, uma de destaque é a pluma de água proveniente da Lagoa dos Patos, gerando no seu entorno uma região com elevada complexidade na dinâmica do escoamento. Além disto, ventos sazonais, sinóticos e variáveis, bem como as condições das correntes costeiras levam a padrões alternantes de escoamentos. Deste modo, foram investigadas ocorrências de estruturas coerentes persistentes neste ambiente. Para tal fim, foi utilizada uma metodologia numérica capaz de descrever as principais características fluidodinâmicas durante um ano climatológico. O código aberto de elementos finitos Telemac-Mascaret foi aplicado no domínio tridimensional, juntamente com o modelo k-épsilon para a descrição dos efeitos turbulentos. Estruturas persistentes de elevada turbulência foram identificadas na área de estudo, as quais ocorrem como perturbações de curvatura definidas por altas taxas de produção e dissipação turbulenta. Como resultado, há um aumento local na mistura entre porções de fluido, caracterizado por um fluxo ascendente. Este fenômeno pode ser atribuído as irregularidades na topografia do leito, associado as tensões de cisalhamento provocadas pela ação do vento. Os resultados obtidos por modelagem numérica contribuíram para aumentar a informação disponível sobre as estruturas de circulação nesta região.

Descritores: Correntes costeiras, Estruturas coerentes, Turbulência, TELEMAC3D, Método dos Elementos Finitos. 


\section{INTRODUCTION}

Investigating the three-dimensional structure of mesoscale eddies along offshore regions is still a challenging task. Their complex dynamics and a lack of field data are the main shortcomings. The yet not fully understood relations of these three-dimensional formations and the associated dynamics of the ocean coherent structures are of great importance for the determination of the role that these phenomena play from smaller towards larger scales.

Turbulent structures in stratified system are responsible for important fluxes on the general circulation and climate as well as for local transport and dispersion of thermal energy and chemical species. Due to the large number of variables that influence the fluid dynamics in an ocean environment, the spatial and temporal structures of turbulent scales present significant variations in horizontal and vertical directions. The three-dimensional structure is responsible for the intensity, endurance and dissipation of the eddy. Strong vertical transport, high values of vertical velocity and vorticity can be caused by the sub-mesoscale structures. These are formed by the interaction between larger scale structures and frontogenetic processes (wind fronts) (Rosso et al., 2014).

Models that describe the ocean dynamics demand methods that represent a combination of multiscale (usually coupled) phenomena under influence of external forces in complex domains. The choice for unstructured grids show several advantages, allowing great control of spatial resolution to represent with accuracy important features of the geometry such as coastlines and bathymetry or embayment and straits (Hill et al., 2012). Nevertheless numerical solutions of ocean models are still limited by the spatial resolution affordable with current computational power.

To analyze the transient behavior of eddy dynamics, satellite altimetry coupled with in situ measurements would be needed. However, to obtain such data is difficult since there are large limitations in time and space resolution (Calado et al., 2010). To overcome this problem, most studies rely on numerical models combined with remote measures (if those are available) to investigate the turbulent structures. Nevertheless, there is a lack of such investigations concerning the Southern Brazilian Shelf (SBS), for which the understanding of the fundamental dynamic characteristics such as momentum, vorticity and spatial energy variations are not complete. Most ocean models rely on standard turbulence closure models, particularly one- or two-equation turbulence schemes such as the Mellor-Yamada level 2.5 and k-epsilon models (Wang and Gan, 2014).

In this context, the aim of this paper is to analyze the three-dimensional structure of a portion of the Southern Brazilian Shelf (SBS) and its dynamic characteristics by means of a validated regional ocean model. We seek to improve the description of the circulation structures through numerical analysis considering all major forcing on the SBS, interaction with shelf and the deep ocean. Furthermore, in order to properly identify the coherent structures, a suitable time scale must be considered to describe the seasonal variability of the region. This is the first study that focuses on the identification of persistent structures during the highly variable seasonal conditions.

\section{MATERIAL AND METHODS}

\section{STUDY AREA}

The South American Atlantic coast is subject to major large scale currents. The Southwestern Atlantic Shelf (SWAS) is the largest continental shelf of the southern hemisphere and a highly biological productive area. A subregion of the SWAS is the SBS, which extend from $35 \mathrm{~S}$ to $28 \mathrm{~S}$ (Figure 1). The influence of astronomical tides, large freshwater discharges and highly variable winds are the driven forces of the circulation pattern in the shelf (Podesta, 1997; Souza and Robinson, 2004). The general circulation is characterized by two major currents. The northeastwards Malvinas Current flows from Patagonia to the La Plata River and the southwestwards Brazilian Current, which flows southward along the continent coast down to a point where it combines with the former, forming the South Atlantic Current, which in turn flows eastwards (Castro et al., 2006; Möller et al., 2008; Rodrigues et al., 2010). The SBS main freshwater sources come from the La Plata River (annual mean discharge of $22,000 \mathrm{~m}^{3} / \mathrm{s}$ ) and the Patos Lagoon (about an order of magnitude lower volume flow rate), the latter composed of a $201,000 \mathrm{~km}^{2}$ drainage basin (Marques et al., 2009; Marques et al., 2011).

Even considering the ecological and social-economic importance of this region, few observation data are available and a small number of numerical studies were developed for the region, usually not for a long enough period of time for annual means or seasonal variability analysis. (Fernandes et al., 2002; Palma et al., 2004; Piola 

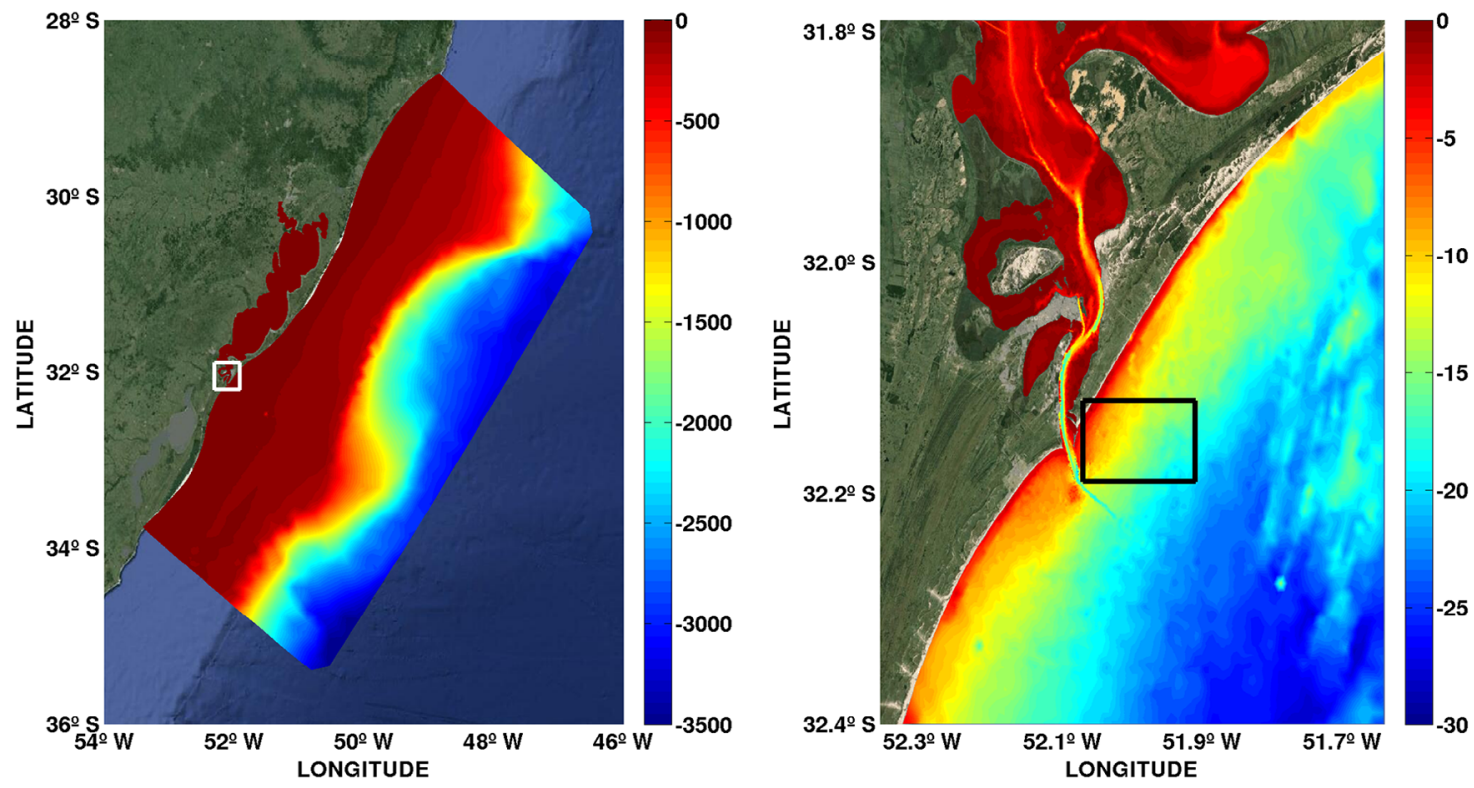

Figure 1. The study regions composed of the Patos Lagoon and adjacent Southern Brazilian Shelf with a detail of the Patos Lagoon discharge region, the black box on the zoomed in picture is the analysis area of this study. The bathymetry data is in meters.

et al., 2008; Marques et al., 2009; Tonini et al., 2013; Stringari et al., 2014).

Altogether there is a predominant southward flow that decreases its intensity during winter. The circulation patterns are reflected by two main water masses that characterize the SBS hydrographic structure. The Subtropical Shelf Water (Salinity $>34$ ) in the north and the Sub-Antarctic Shelf Water (Salinity <34) in the south. These are separated by the density compensated Subtropical Shelf Front (Piola et al., 2000).

A northeastward high-salinity inflow occurs during fallwinter and a southward low-salinity from La Plata River during spring-summer in the southern portion of this region. The northern region is characterized by a southward flow that decreases its intensity during winter. Both waters are separated by the Subtropical Shelf Front (32 S).

The intensity of wind stress is weak yet with significant seasonal variations and the tidal amplitudes are relatively small (Palma et al., 2004; Palma et al., 2008). The wind field is dominantly northeast (NE) during summer and southwest (SW) during winter (Piola et al., 2005; Braga and Krusche, 2000), thus affecting the coastal circulation (Möller et al., 2008; Marques et al., 2009; Marques et al., 2010; Marques et al., 2011). It is worth mentioning that these winds are enhanced by the El Nino Southern Oscillation (ENSO) events (Piola et al., 2005).

\section{MODEL IMPLEMENTATION}

In this study the open-source Telemac-Mascaret model is used to solve the three-dimensional and transient flow in the ocean environment. A detailed theoretical description of the numerical formulation is given by (Hervouet, 2007; Hervouet and Van Haren, 1996). This model uses a finiteelement method to solve the Navier-Stokes equations and the transport-diffusion equation of scalar quantities such as temperature and salinity. The free-surface flow is considered to be incompressible and the Boussinesq approximation is applied. The Reynolds-Averaged NavierStokes (RANS) k-epsilon model is used for the description of the turbulence in the ocean current flow. This isotropic model considers the Boussinesq eddy viscosity hypothesis and consists of two transport equations for the production and dissipation of turbulence energy, closed by semiempirical standard constants (Pope, 2000).

Grid horizontal resolution affects the vertical motion in numerical simulations (Rosso et al., 2014), hence sufficient grid resolution for resolving eddies is necessary. The numerical domain covers the southern region of the Brazilian shore, including the estuarine region of the Patos Lagoon. The unstructured mesh uses 15 levels in sigmacoordinates for vertical resolution and horizontal grid spacing of $\sim 0.8 \mathrm{~km}$ near the coast increasing to $\sim 10-20 \mathrm{~km}$ at outer boundary region for the ocean. Also a horizontal 
spacing ranging from $\sim 0.05 \mathrm{~km}$ to $\sim 1 \mathrm{~km}$ in the lagoon region was applied, as can be seen in Figure 2. Thus, the mesh consists of 111,106 nodes horizontally, which yields about 1.6 million nodes in total. At this resolution the minimum number of nodes by Rossby radius of deformation is about $2(20-40 \mathrm{~km})$. According to Malone et al. (2003) and Masumoto et al. (2004) global models using finite difference methods relies on $1 / 10^{\circ}$ to $1 / 12^{\circ}$ of resolution to prescribe correctly large eddies. Therefore, the grid resolution was considered to be eddy-resolving for our study area. The Rossby radius of deformation is a horizontal scale relating the effects on fluid dynamics by the rotation of the Earth. The mesoscale motion is of the same order as the first baroclinic Rossby radius of deformation (Osinski et al., 2010).

The bottom topography follows the bathymetric data from ETOPO2 (1/30Deg) from National Geophysical Data Center (GEBCO). Lateral open boundaries are forced for water levels, current velocity, salinity and temperature, with data acquired from the HYCOM + NCODA Global $1 / 12^{\circ}$ Reanalysis using datasets (GLBa0.08) from several experiments ranging from 2003 to 2014 data range (i.e expt_60.5, expt_90.2, expt_90.3, expt_90.6, expt_90.8, expt_91.1),(HYCOM, 2015). Tidal amplitudes and phases on these boundaries are interpolated from the global tidal model OTPS (Egbert and Erofeeva, 2002), which is natively assimilated into Telemac-Mascaret code (Pham et al., 2013). Additionally, a constant annual-averaged discharge of three major rivers into the Patos Lagoon is set, according to information of the Brazilian National Water Agency (ANA, 2015). The atmospheric conditions forcing the free surface are calculated using the National Oceanic \& Atmospheric Administration (NOAA, 2015) reanalysis data. The forcing conditions are time-dependent, updated every 6 hours for atmospheric conditions and every 24 hours for the oceanic boundaries. Since the aim of this paper is to analyze persistent structures, the model was run in hindcast using a climatological year consisting of a 12-years mean (2003 - 2014) of surface and lateral boundary conditions. A constant time step of $90 \mathrm{~s}$ was kept for the simulation during the entire climatological year.

The initial condition considered current, temperature and salinity condition for the ocean and a static constant salinity and temperature condition for the Patos Lagoon, due to the absence of observed data. The initial water level was fixed to $0.75 \mathrm{~m}$, the approximate mean tide height of the region (Möller et al., 2001).

\section{Calibration AND VAlidation}

Even though the model ability to represent the circulation of the Patos Lagoon and adjacent coastal region was demonstrated by previous studies (Marques et
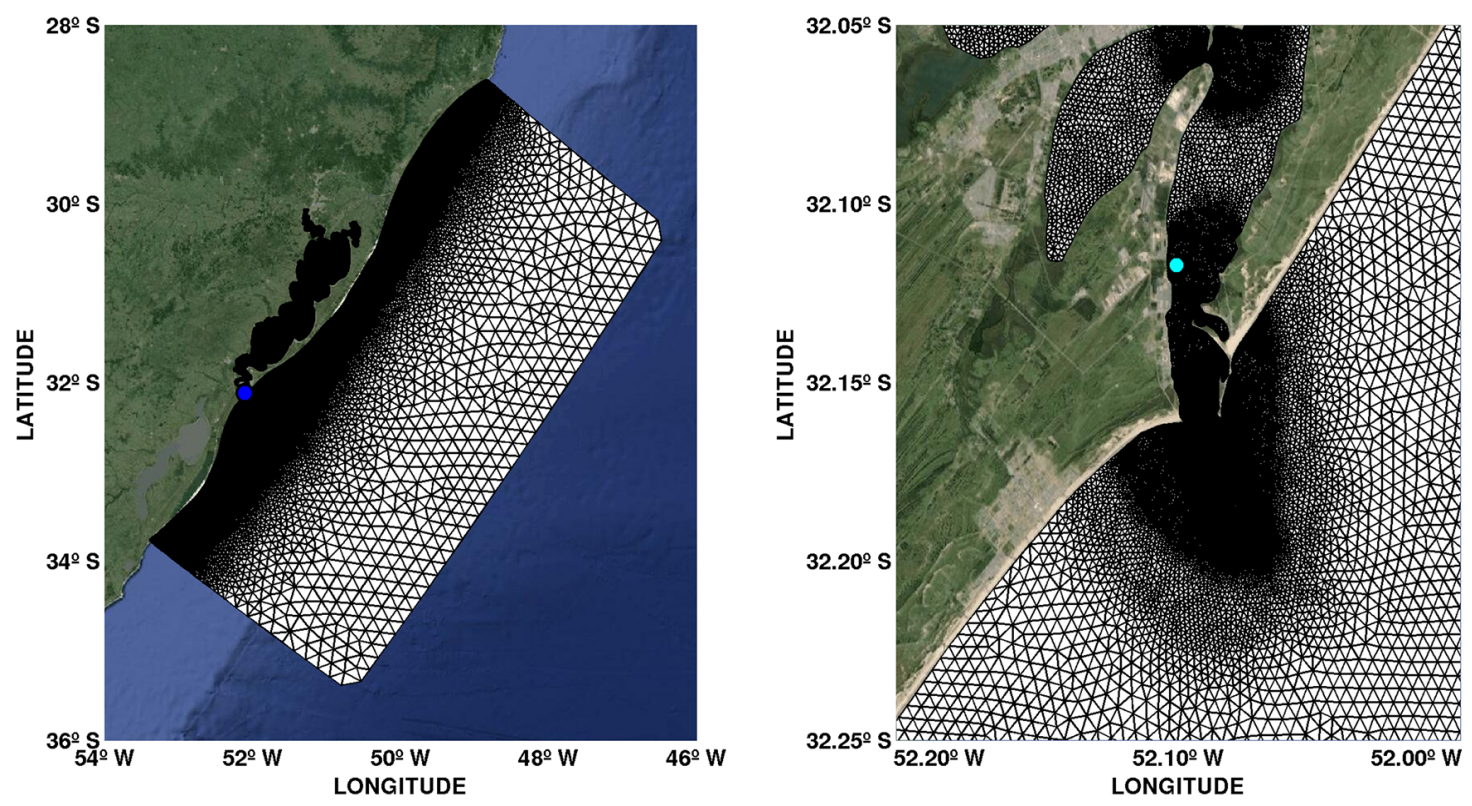

Figure 2. Numerical mesh of the domain, where the dots represent the locations of measured data available for validation. 
al., 2009; Marques et al., 2010a; Marques et al., 2010b; Marques et al., 2011; Kirinus et al., 2015), additional validation of the numerical results with available observations are presented. The experience gathered by those previous studies were crucial for establishing values for many physical parameters (such as the wind influence coefficient and friction coefficient), which were used to conduct this study.

For the calibration of the climatologically averaged simulation no observed data for an uninterrupted long period of time was available. Therefore the same mesh, numerical parameters and methodology were applied to a simulation covering a shorter period of time with existing observed data.

The simulation was conducted comprising the period of December 2010 to January 2011, where only the last month was considered. The observed data was collected in the Patos Lagoon channel to the ocean $\left(32^{\circ} 07^{\prime} \mathrm{S}\right.$, $\left.52^{\circ} 06^{\prime} \mathrm{W}\right)$ with an ADCP positioned at $-17 \mathrm{~m}$. The comparison of superficial and bottom current velocity for the numerical result and observed data for this period is shown in Figure 3.
Time series of the velocity oscillations during the calibration period provide a visual representation of the comparison between model and observed data. Nevertheless, further evaluations using well known performance skills and statistical metrics can enhance the comparison (Willmot, 1982; Janssen et al., 1997; Wilks, 2006; Chawla et al., 2013; Teegavarapu, 2013). Therefore, a statistical analysis was performed for the time series, including the parameters described next. The Root Mean Square Error (RMSE), Mean Absolute Error (MAE) and Mean Square Error (MSE) indicate the accuracy of the simulation, best results when errors tend to 0 (Wilks, 2006). Another parameter, the Index of Concordance (IC) of Willmot (Willmot, 1982) represents the ability of the model to reproduce the observations, meaning that if IC $=1$ then the simulation is perfect, otherwise, if IC tends to zero the numerical result is unacceptable. The Relation of Variance (RVAR) was also applied, since this skill indicates that the variance of the observed and modeled data is the same (best result must be closer to 1).

Performance skills for the validation are presented in Table 1. The high IC values indicate that the model can
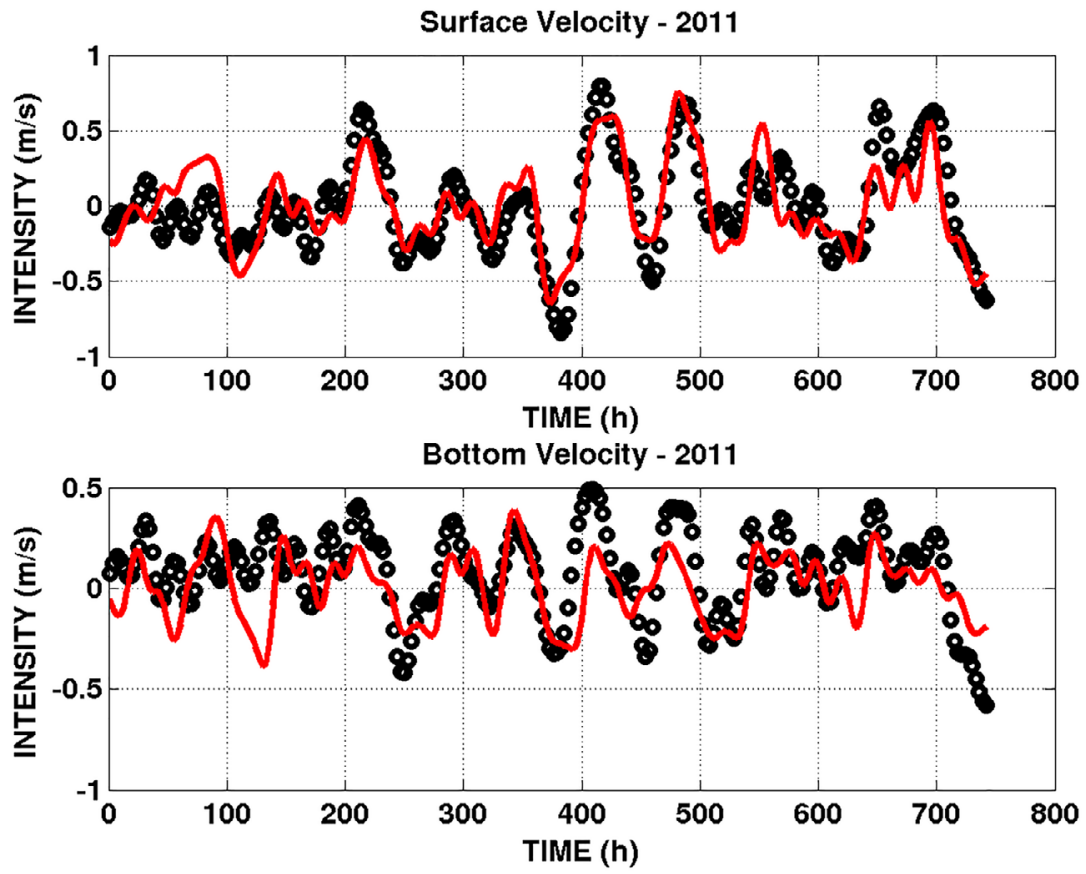

Figure 3. Comparison between the numerical simulation (red line) and the observed data (black dots) during January 2011. 
Table 1. Performance skills for model validation.

\begin{tabular}{lcc}
\hline Skill & Superficial velocity & Bottom velocity \\
\hline RMSE & 0.199 & 0.201 \\
MAE & 0.165 & 0.158 \\
MSE & 0.040 & 0.040 \\
IC & 0.917 & 0.868 \\
RVAR & 0.780 & 0.641 \\
\hline
\end{tabular}

predict well the observations, in addition to acceptable values of MAE, RMSE and MSE. RVAR is related to the variance of the data, since it represents the distance between the data and its average. Thus, RVAR results point out that the model is able to represent overall velocity patterns, particularly more promptly on the surface.

The validation process found similar values consistent to other numerical evaluation (Hashemi et al., 2015). Furthermore, considering that January is a month of high variability in wind condition, the model was considered satisfactory for the representation of the hydrodynamics of the Patos Lagoon discharge to the adjacent coastal region.

\section{RESULTS}

The circulation pattern is more intense in the shallow region near the $25 \mathrm{~m}$ isobath (Figure $4 \mathrm{a}$ ). The salinity in this area changes smoothly towards fall, winter and spring (Figure $4 \mathrm{c}, \mathrm{d}, \mathrm{e}$ ), although during winter the regular presence of alternating wind directions results in a prevailing south-northern wind-driven current forced by the passage of meteorological systems that promotes the dispersion of the Patos Lagoon plume northwards (Marques et al., 2010a), associated with high freshwater discharge (Barros and Marques, 2012). The opposite is seen in the summer (Figure $4 \mathrm{f}$ ), when the northern winds prevail upon the Patos Lagoon plume enhancing the salinity on the coast in addition to lower river discharge into the lagoon.

All these factors enhance the highly dynamic dominance near the Patos Lagoon jetties, in fact, a distinct feature on the current pattern was remarkably distinguished from the regular dynamics (Figure 4b). The feature is more than $20 \mathrm{~km}$ away from the coast ranging from 3 to $6 \mathrm{~km}$ of diameter and being widely marked by seasonality and irregular topography gradients.

From Figure 5 it is seen that the persistent coherent structures present similar vertical distribution. Along the surface (Figure 5a) the direction of rotation is cyclonic resulting in local net inflow towards the surface. In the middle of the water layer (Figure $5 \mathrm{~b}$ ), distinct vorticity patterns are observed, characterized by asymmetric intensities with rotation direction being primarily anticyclonic. Near the bottom the net flow rotates mainly cyclonic (Figure $5 \mathrm{c}$ ).

Vertical transects cutting through the persistent meanders (indicated by the line in Figure 5) of turbulent kinetic energy $(\mathrm{k})$ and eddy dissipation rate (epsilon) are presented in Figure 6. The distribution of turbulent energy was consistent with the flow behavior and had larger values near the surface and bottom, due to shear stress at the water-air and water-seabed interfaces respectively.

The source of the superficial turbulent kinetic energy (Figure 6a) is related with the wind variability and strong near-surface dynamics (Marques et al., 2010b). At the bottom, however, for the first and second eddies relatively low levels of turbulent kinetic energy are generated. For the last eddy, however, the bottom energy source is connected with the bathymetric slope, which intensifies the superficial energy as well. The production of turbulent energy is associated with regions of strong fluid motion (Wang et al., 2014).

The spots with high turbulent kinetic energy are also related with high eddy dissipation rate (Figure $6 \mathrm{~b}$ ). This is due to friction forces imposed by the wind and topography on the surface and bottom boundary respectively resulting in stronger velocity gradients and thus in enhanced mixture.

Furthermore, Figures 6 c) and d) reflect the turbulent effects on the temperature and salinity vertical fields. A change in the local flow direction leads to upwelling, creating local gradients. This effect is enhanced by the presence of a nearby low salinity and momentum source from the Patos Lagoon discharge to the ocean, which may be an additional reason for the persistence of this near coast structures.

The associated mean advection pattern (Figure 7) indicates a vigorous three-dimensional mixing effect. The local water masses and the spatial dimension of these structures produce a strong upward circulation flow. 


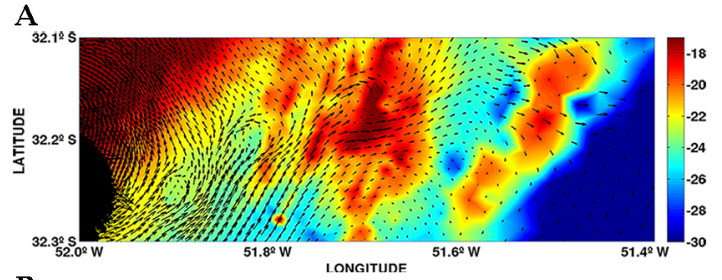

B

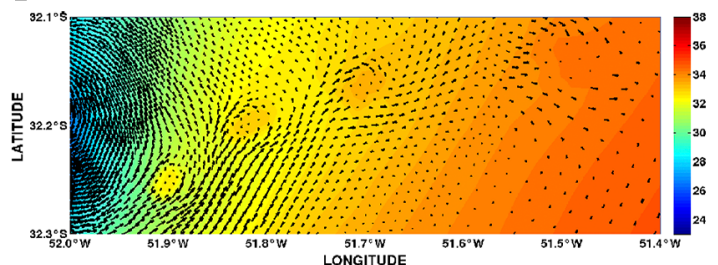

C.

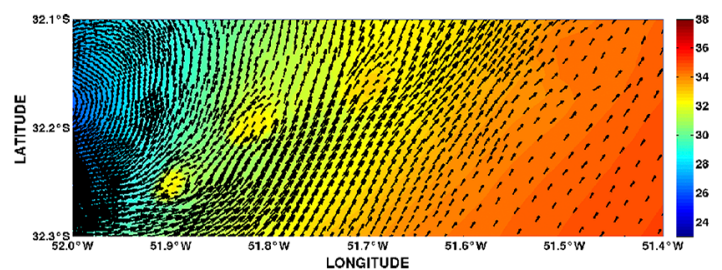

D

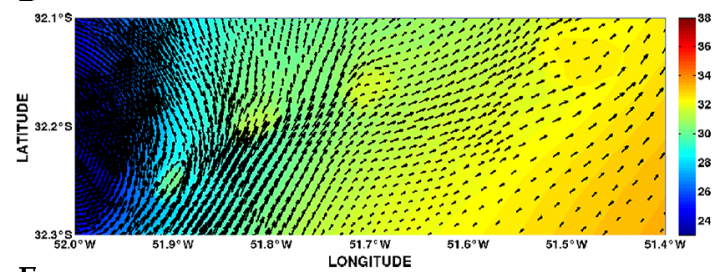

E

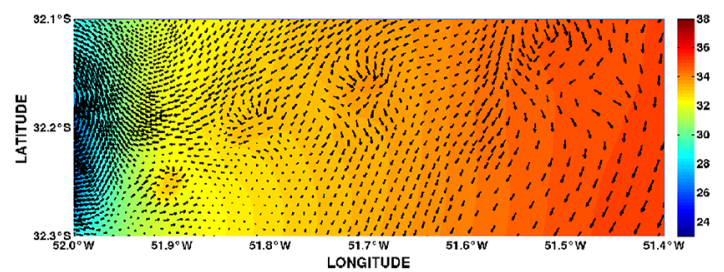

F

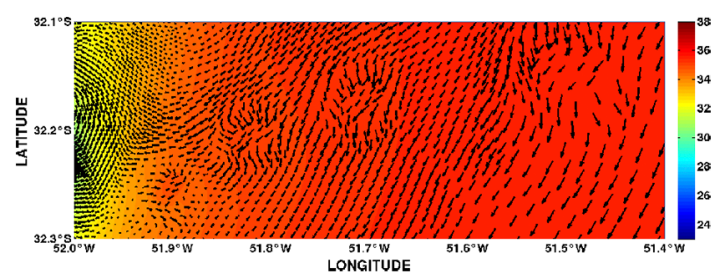

Figure 4. a) bathymetric information of the region near the jetties, in meters. Velocity vectors for the surface and salinity contour in PSU for: b) climatological average c) fall average; d) winter average; e) spring average; f) summer average.

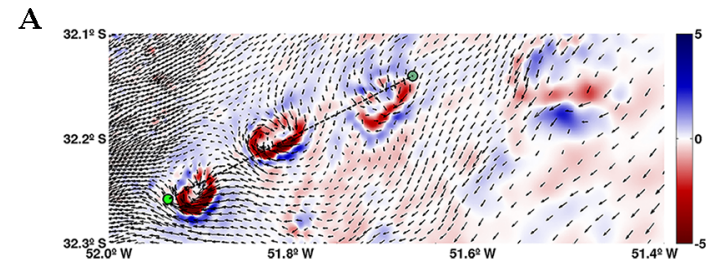

B

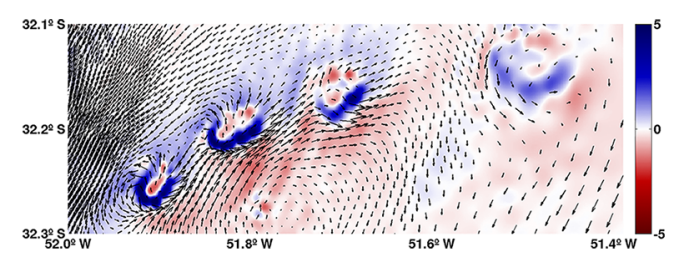

C

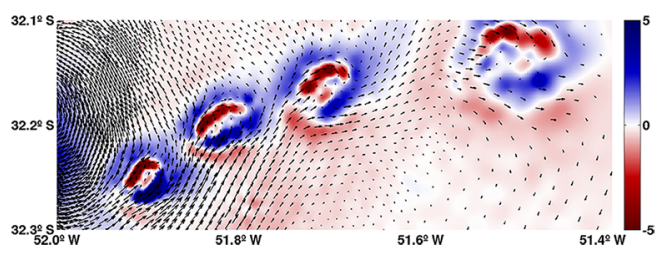

Figure 5.a) Mean horizontal vorticity fields (s-1) and mean velocity vectors located: a) surface; b) intermediate level (sigma 9); c) near the bottom (sigma 14).

Variations in bottom topography lead to an increase in potential vorticities which in turn enhance vertical mixing, due to the Eckman dynamics (Jacobs et al., 1999).

\section{DISCUSSION}

The intersection of different water masses characterizes the hydrodynamic condition of the Patos Lagoon discharge and adjacent coastal region (Costa and Möller, 2011). The climatological analysis depicted the mean season variability, being fitted for persistent structure identification.

The Patos Lagoon discharge is located in an indent where the $50 \mathrm{~m}$ isobath moves away from the shore. Within this isobath, the area is marked by rough and irregular topography nearby the jetties and shoreline. This region is subject to prevailing NE winds associated to a high-pressure center of the South Atlantic, characterized by higher intensities during summer (Costa and Moller, 2011). Periodic reversals in wind direction (S, SE and SW) occur due to meteorological fronts and the coastal currents 
A

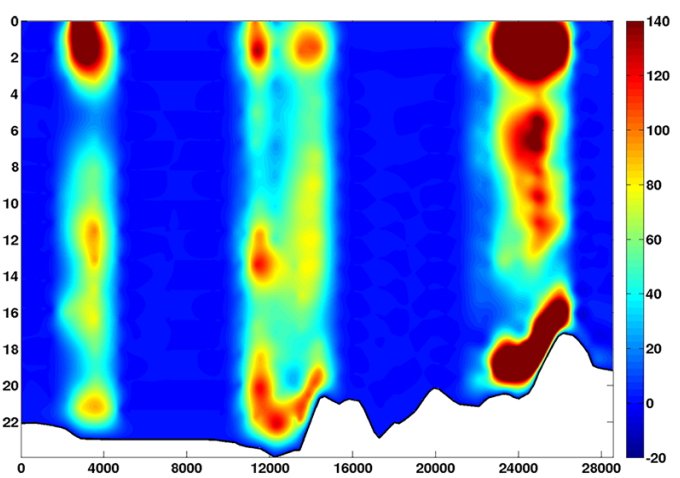

B

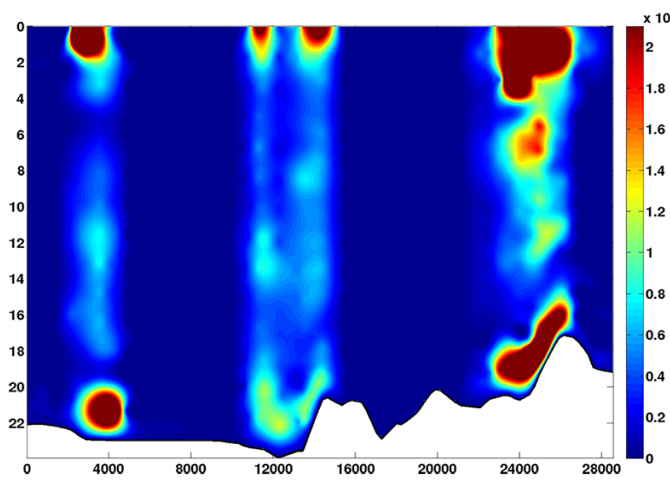

C

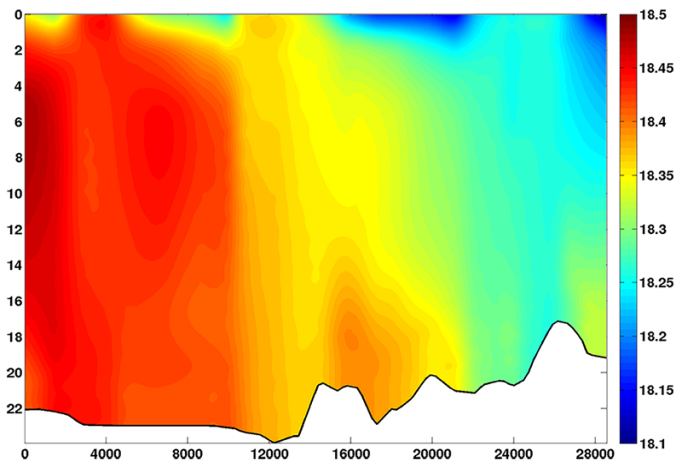

D

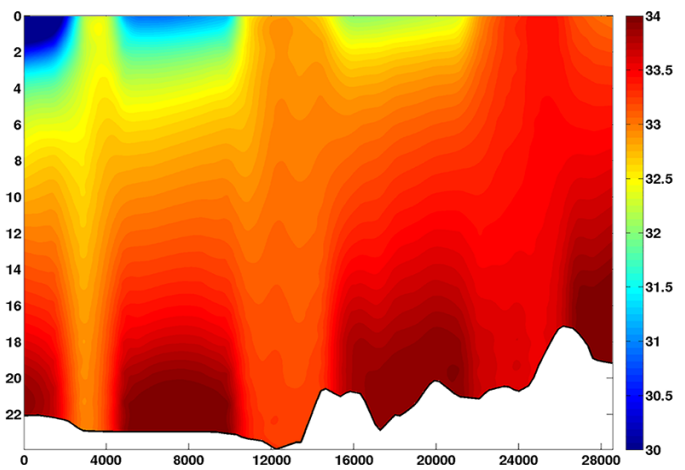

Figure 6.a) Mean vertical fields along the persistent structures of: a) turbulent kinetic energy $(\mathrm{k})$ in $\mathrm{m}^{2} / \mathrm{s} 2 ; \mathrm{b}$ ) eddydissipation rate (epsilon) in $\mathrm{m}^{2} / \mathrm{s} 3 ; \mathrm{c}$ ) temperature in ${ }^{\circ} \mathrm{C}$; d) salinity in PSU.
A

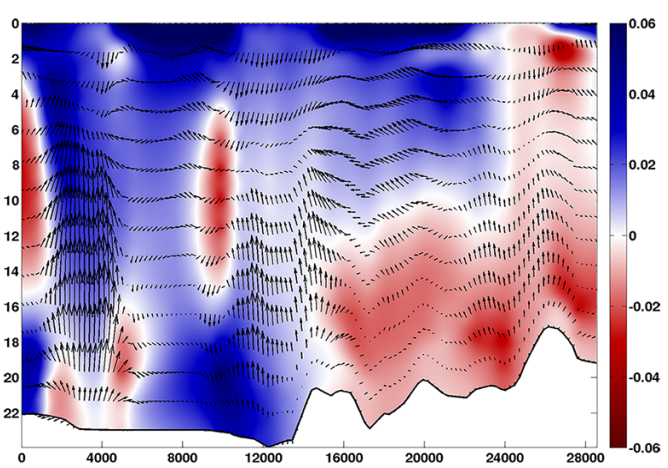

B

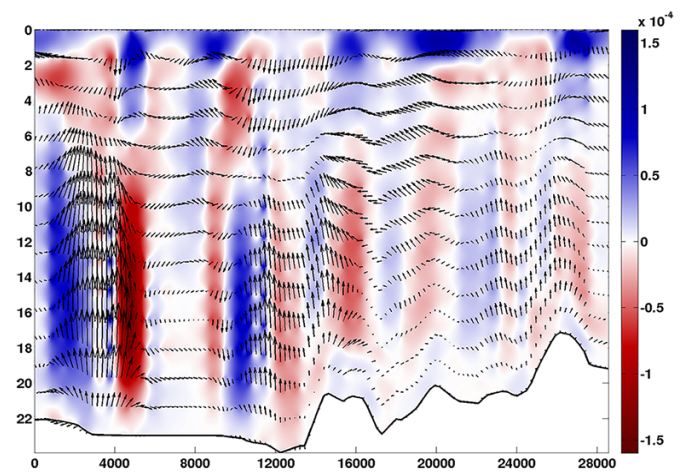

Figure 7.a) Mean vertical fields of: a) normal velocity with mean velocity vectors in $\mathrm{m} / \mathrm{s}$; b) vorticity ( $\mathrm{s}-1$ ) with mean velocity vectors.

follow this atmospheric variability (Soares and Möller Jr, 2001; Zavialov et al., 2002; Marques et al., 2010b). Additionally, the discharge of the Patos Lagoon into the ocean, which has a frequent variability in current direction and intensity, contributes to the dynamic behavior of this region.

The average of the climatological-year simulation (Figure $4 \mathrm{~b}$ ) indicates the presence of persistent structures along the coast. Winter-spring season is characterized by the highest precipitation rates of the year, which associated with the local wind pattern drive the current northwards (Figure $4 \mathrm{~d}$ and Figure $4 \mathrm{e}$ ). This predominant flow direction creates a series of submesoscale eddies north of the jetties from the Patos Lagoon discharge area. On the other hand during the summer-fall period (Figure $4 \mathrm{f}$ and Figure $4 \mathrm{c}$ ) the wind and thus current flow invert direction. The identified eddies for the former period were also observed under these conditions.

The local influence of these features affects the salinity field in the way of increasing the salinity inside the vortex (Figure 4). This increase is due to the direction of the vortex which is able to pump salinity from the bottom to the surface, breaking a layer of brackish water from the Patos Lagoon plume, resulting in salinities up to $2 \mathrm{PSU}$ 
higher inside the vortex. The vertical salinity field (Figure $6 d)$ enlightens the mechanism of salinity pump towards the surface, which also works in the opposite way, bringing sub-surface less salty water (32.5PSU) to the bottom. Thus, this mechanism promotes vertical mixture in the first and second eddies, which results in a high stratified layer with high eddy dissipation rates as well. The third eddy shows a different behavior once it remains dynamically stable without stratifications and also with high turbulent kinetic energy and dissipation rates (Figures $6 \mathrm{a}$ and $\mathrm{b}$ ).

The presence of persistent structures occurs as a disturbance in the current flow, generating a highly curvilinear flow region characterized by a series of meanders and eddies. Turbulence associated with this region implies higher production and dissipation rates for turbulent flow energy (Marques et al., 2010a). Therefore, vorticity fields are needed in order to comprehend the influence towards the entire water layer. From Figure 5, the results showed structures that become wider and stretched toward the surface, due to the increased influence of wind stress forces near the surface. The pattern of vorticity corroborates with the salinity pump observed before.

The model results suggest that the persistent year-long coherent structures are one additional characteristic of the local hydrodynamic behavior. The structures presence and effect on the local flow could be taken under consideration by plume dispersion studies, since the described process indicates that sediments would not settle easily there.

\section{CONCLUSION}

The application of a three-dimensional numerical investigation on the turbulent features along the coast proved to be an important tool to investigate persistent coherent structures. In particular, the region near the Patos Lagoon discharge to the ocean has presented persistent yearlong circulation patterns. Despite the seasonal variations, the structures positions remained fairly restricted to a specific location, indicating that this region is characterized by strong mixture and upwelling. In addition, the numerical model shed some light on the mechanisms behind these coherent structures. The first and second studied eddies are strongly influenced by frontogenesis being remarkably controlled by mechanisms such as high mixture, high stratification and also riverine influence through the Patos Lagoon plume. On the other hand the third eddy is in fact controlled by topographical features which generate and dissipate turbulent energy increasing potential vorticities resulting in vertical mixing. Furthermore, wind stress and bottom shear both play a significant role in this highly dynamic region regulating changes in water density through these eddies. Finally, it was possible to improve the description of the study area circulation structures by means of numerical modelling analysis.

\section{ACKNOWLEDGMENTS}

The authors are grateful to the Coordenação de Aperfeiçoamento de Pessoal de Nível Superior (CAPES) to the Programa Nacional de Pós-Doutorado - PNPD and the Conselho Nacional de Desenvolvimento Científico e Tecnológico (CNPq) under contract 304227/2016-1. Further acknowledgments go to the Brazilian Navy for providing detailed bathymetric data for the coastal area; the Brazilian National Water Agency and NOAA for supplying the fluvial discharge and to the Open Telemac-Mascaret Consortium for the freely distribution of the TELEMAC system.

\section{REFERENCES}

ANA (Agência Nacional de Águas). 2015. Available from: http:// www.ana.gov.br (last access: 20 Oct 2015).

BARROS, G. P. \& MARQUES, W. C. 2012. Long-term temporal variability of the freshwater discharge and water levels at Patos Lagoon, Rio Grande do Sul, Brazil. International Journal of Geophysics, 2012, 1-11. DOI. 10.1155/2012/459497

BRAGA, M. F. \& KRUSCHE, N. 2000. Padrão de ventos em Rio Grande, RS, no período de 1992 a 1995. Atlântica, 22, 27-40.

CALADO, L., SILVEIRA, I. C. A., GANGOPADHYAY, A. \& CASTRO, B. M. 2010. Eddy-induced upwelling off Cape São Tomé (22 ${ }^{\circ} \mathrm{S}$, Brazil). Continental Shelf Research, 30, 1181-1188.

CASTRO, B. M., LORENZZETTI, J. A., SILVEIRA, I. C. A. \& MIRANDA, L. B. 2006. Estrutura termohalina e circulação na região entre o Cabo de São Tomé (RJ) e o Chuí (RS). In: ROSSI-WONGTSCHOWSKI, C. L. B., MADUREIRA, L. S. P. (eds.) O ambiente oceanográfico da plataforma continental e do talude na região sudeste-sul do Brasil. São Paulo: Edusp, p. 11-20.

CHAWLA, A., SPINDLER, D. M. \& TOLMAN, H. L. 2013. Validation of a thirty year wave hindcast using the Climate Forecast System Reanalysis winds. Ocean Modelling, 70, 189-206.

COSTA, R. L. \& MÖLLER, O. O. 2011. Study of the structure and variability of currents in the area of the inner shelf off Rio Grande (RS, Brazil), southwest of the South Atlantic during spring-summer 2006-2007. Journal of Integrated Coastal Zone Management, 11, 273-281.

EGBERT, G. D. \& EROFEEVA, S. Y. 2002. Efficient Inverse Modeling of Barotropic Ocean Tides. American Meteorological Society, 19, 183-204.

FERNANDES, H. H. L., DYER, K. R., MOLLER, O. O., NIENCHESKI, L. F. H. 2002. The Patos Lagoon hydrodynamics during an El Niño event (1998). Continental Shelf Research. 22, 1699-1713. 
HASHEMI, M. R., NEILL, S. P., ROBINS, P. E., DAVIES, A. G. \& LEWIS, M. J. 2015. Effect of waves on the tidal energy resource at a planned tidal stream array. Renewable Energy, 75, 626-639.

HERVOUET, J. M. 2007. Free surface flows: Modelling with the finite element methods, Chichester, John Wiley \& Sons.

HERVOUET, J. M. \& VAN HAREN, L. 1996. Recent advances in numerical methods for fluid flows. In: ANDERSON, M., WALLING, D. \& BATES, P. D. (eds.) Floodplain processes. Chichester: John Wiley \& Sons, p. 183-214.

HILL, J., PigGOTT, M. D., HAM, D. A., POPOVA, E. E. \& SROKOSZ, M. A. 2012. On the performance of a generic length scale turbulence model within an adaptive finite element ocean model. Ocean Modelling, 56, 1-15.

HYCOM (Hybrid Coordinate Ocean Model). 2015 Available from: https://hycom.org (last access: 20 Oct 2015).

JACOBS, P., GUO, Y. \& DAVIES, P. A. 1999. Boundary current over shelf and slope topography. Journal of Marine Systems, $19,137-158$.

JANSSEN, P. A. E. M., HANSEN, B. \& BIDLOT, J. R. 1997. Verification of the ECMWF Wave Forecasting System against Buoy and Altimeter Data. American Meteorological Society, 12, 763-784.

KIRINUS, E. P., MARQUES, W. C., JUNG, B. M., STRINGARI, C. E. \& MATZENAUER, H. B. 2015. Evaluating current power availability for energy conversion along the Southern Brazilian Shelf. International Journal of Marine Energy, 10, 97-112.

MALONE, R. C., SMITH, R. D., MALTRUD, M. E. \& HECHT, M. W. 2003. Eddy-Resolving Ocean Modeling. Los Alamos Science, 28, 223-231.

MARQUES, W. C., FERNANDES, E. H., MONTEIRO, I. O. \& MÖLLER, O. O. 2009. Numerical modeling of the Patos Lagoon coastal plume, Brazil. Continental Shelf Research, $29,556-571$.

MARQUES, W. C., FERNANDES, E. H., MÖLlER, O. O., MORAES, B. C. \& MALCHEREK, A. 2010a. Dynamics of the Patos Lagoon coastal plume and its contribution to the deposition pattern of the southern Brazilian inner shelf. Journal of Geophysical Research, 115, C10045.

MARQUES, W. C., FERNANDES, E. H. L., MONTEIRO, I. O., MOLLER Jr., O. O. 2009. Numerical modeling of the Patos Lagoon coastal plume, Brazil. Continental Shelf Research, $29,556-571$

MARQUES, W. C., FERNANDES, E. H. L. \& MÖLLER, O. O. 2010b. Straining and advection contributions to the mixing process of the Patos Lagoon coastal plume. Journal of Geophysical Research, 115, C06019.

MARQUES, W. C., FERNANDES, E. H., ROCHA, L. A. O. \& MALCHEREK, A. 2011. Energy converting structures in the southern brazilian shelf: energy conversion and its influence on the hydrodynamic and morphodynamic processes. Journal of Earth Sciences and Geotechnical Engineering, 1, 61-85.

MASUMOTO, Y., SASAKI, H., KAGIMOTO, T., KOMORI, N., ISHIDA, A., SASAI, Y., MIYAMA, T., MOTOI, T., MITSUDERA, H., TAKAHASHI, K., SAKUMA, H. \& YAMAGATA, T. 2004. A Fifty-Year Eddy-Resolving Simulation of the World Ocean: Preliminary Outcomes of OFES (OGCM for the Earth Simulator). Journal of the Earth Simulator, 1, 35-56.
MÖlleR JR, O. O., PIOLA, A. R., FREITAS, A. C. \& CAMPOS, E. J. D. 2008. The effects of river discharge and seasonal winds on the shelf off southeastern South America. Continental Shelf Research, 28, 1607-1624.

NOAA (National Oceanic \& Atmospheric Administration). 2015 Available from: http://www.cdc.noaa.gov/data/reanalysis/ reanalysis.shtml (last access: 20 Oct 2015)

OSINSKI, R., RAK, D., WALCZOWSKI, W. \& PIECHURA, J. 2010. Rossby radius of deformation in the southern Baltic Sea. Oceanologia, 52, 417-429.

PALMA, E. D., MATANO, R. P. \& PIOLA, A. R. 2004. A numerical study of the Southwestern Atlantic Shelf circulation: Barotropic response to tidal and wind forcing. Journal of Geophysical Research, 109, C08014.

PALMA, E. D., MATANO, R. P. \& PIOLA, A. R. 2008. A numerical study of the Southwestern Atlantic Shelf circulation: Stratified ocean response to local and offshore forcing. Journal of Geophysical Research, 113, C11010.

PHAM, C., BOURBAN, S., DURAND, N. \& TURNBULL, M. 2013. Méthodologie pour la simulation de la marée avec la version 6.2 de TELEMAC-2D et TELEMAC-3D, Chateau, EDF.

PIOLA, A. R., CAMPOS, E. J., MÖLLER JR, O. O., CHARO, M. \& MARTINEZ, C. 2000. Subtropical shelf front off eastern South America. Journal of Geophysical Research, 105, 6565-6578.

PIOLA, A. R., MATANO, R. P., PALMA, E. D., MÖLLER JR, O. O. \& CAMPOS, E. J. 2005. The influence of the Plata River discharge on the western South Atlantic shelf. Geophysical Research Letters, 32, L01603.

PIOLA, A. R., ROMERO, S. I. \& ZAJACZKOVSKI, U. 2008. Space-time variability of the Plata plume inferred from ocean color. Continental Shelf Research, 28, 1556-1567.

PODESTA, G. P. 1997. Utilizacion de datos satelitarios en investigaciones oceanogracas y pesqueras en el Oceano Atlantico Sudoccidental. In: BOSCHI, E. E. (ed.) El mar argentino y sus recursos pesqueros. Mar del Plata: INIDEP, p. $195-222$.

POPE, S. B. 2000. Turbulent Flows, Cambridge, Cambridge University Press.

RODRIGUES, R. R., WIMBUSH, M., WATTS, D. R., ROTHSTEIN, L. M. \& OLLITRAULT, M. 2010. South Atlantic mass transport obtained from subsurface float and hydrographic data. Journal of Marine Research, 68, 819-850.

ROSSO, I., HOGG, A. M., STRUTTON, P., KISS, A. E., MATEAR, R., KLOCKER, A. \& VAN SEBILLE, E. 2014. Vertical transport in the ocean due to sub-mesoscale structures: Impact in the Kerguelen region. Ocean Modelling, $80,10-23$.

SOARES, I. \& MÖLLER JR, O. 2001. Low-frequency current and water mass spatial distribution on the southern Brazilian shelf. Continental Shelf Research, 21, 1785-1814.

SOUZA, R. B. \& ROBINSON, I. S. 2004. Lagrangian and satellite observations of the Brazilian Coastal Current. Continental Shelf Research, 24, 241-262.

STRINGARI, C. E., MARQUES, W. C., MELLO, L. F., EIDT R. T. 2014. Application of Telemac - ECOS modelling system at the Southern Brazilian Shelf: Influence of Coastal Currents in Tramandai Oil Spilll. Marine Systems \& Ocean Technology, $9,105-112$ 
TEEGAVARAPU, R. S. V. 2013. Floods in a Changing Climate: Extreme Precipitation, Cambridge, Cambridge University Press.

TONINI, M. H., PALMA, E. D., PIOLA, A. R. 2013. A numerical study of gyres, thermal fronts and seasonal circulation in austral semi enclosed gulfs. Continental Shelf Research, 65, 97-110

VILLARET, C., HERVOUET, J. M., KOPMANN, R., MERKEL, U. \& DAVIES, A. G. 2013. Morphodynamic modeling using the Telemac finite-element system. Computers \& Geosciences, 53, 105-113.

WANG, L. \& GAN, J. 2014. Delving into three-dimensional structure of the West Luzon Eddy in a regional ocean model. Deep Sea Research Part I: Oceanographic Research Papers, 90, 48-61.
WILKS, D. S. 2006. Statistical methods in the atmospheric sciences, London, Elsevier.

WILLMOT, C. J. 1982. Some Comments on the Evaluation of Model Performance. Bulletin of the American Meteorological Society, 63, 1309-1313.

ZAVIALOV, P., MÖLLER JR, O. O. \& CAMPOS, E. 2002. First direct measurements of current on the continental shelf of Southern Brazil. Continental Shelf Research, 22, 1975-1986. 